ELORE (ISSN 1456-3010), vol. 18 - 2/2011.

Julkaisija: Suomen Kansantietouden Tutkijain Seura ry.

[http://www.elore.fi/arkisto/2_11/salonsaari.pdf]

\title{
AJANKOHTAISTA
}

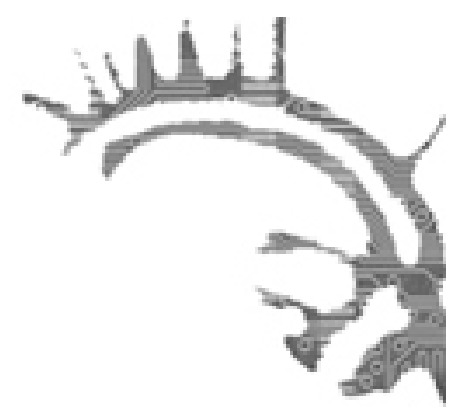

\section{Puhetta KultTUURIPERINNÖStä JA YKSILÖISTÄ}

\author{
Minna-Liisa Salonsaari \\ Heritage and Individuals, \\ 3rd Conference of the SIEF Working Group on Cultural Heritage and Property, \\ 14.-17.9.2011, Pori Finland
}

Etnologian ja folkloristiikan kansainvälisen verkoston Societé Internationale d'Ethnologie et de Folklore (SIEF) Cultural Heritage and Property -työryhmän kolmas kansainvälinen konferenssi järjestettiin syyskuussa Porin yliopistokeskuksessa, Turun yliopiston kulttuurituotannon ja maisemantutkimuksen koulutusohjelman kulttuuriperinnön tutkimuksen oppiaineen kotipaikassa. Konferenssityöryhmän ja kulttuurituotannon ja maisemantutkimuksen koulutusohjelman lisäksi järjestäjinä toimivat Suomen kansatieteilijöiden yhdistys Ethnos ry., Suomen Kansantietouden Tutkijain Seura sekä Tulevaisuuden tutkimuskeskus.

Heritage and Individuals -konferenssin teemoissa syvennyttiin erilaisiin ja moninaisiin näkemyksiin aineellisesta ja aineettomasta kulttuuriperinnöstä, menneen ja nykyisen välillä tapahtuvasta kulttuurisesta muutoksesta, kulttuuriperinnön yksilöllisistä ja yhteisistä määritelmistä ja käytöstä sekä kulttuurisesti kestävästä kehityksestä. Kahden päivän aikana osallistuttiin keynote-puhujien sekä lukuisien työryhmäpuheenvuorojen kautta keskusteluihin kulttuuriperinnöstä.

Kulttuuriperintö on tänä päivänä varsin trendikäs käsite. Keskustelujen aiheet ovat vaihdelleet maailmanperintökohteista yksittäisten yksilöiden ja perheiden kulttuuriperintöön. Porissa kulttuuriperinnön oppiaineessa on jo kymmenen vuoden ajan tarkasteltu aineellisen ja aineettoman kulttuuriperinnön syntyä, muutosta ja välittymistä osana ihmisten arkea, kommunikaatiota ja identiteettiä. Kiinnostus on kohdistunut erityisesti niihin prosesseihin ja mekanismeihin, joiden kautta joistakin asioista syntyy kulttuuriperintöä ja joistakin ei. Lähtökohtana näissä prosesseissa on aina ollut ihminen, yksilö, joka on eri aikoina tehnyt erilaisia valintoja suhteessa kulttuuriperintöön. Juuri siksi myös konferenssi Heritage and Individuals sopi erinomaisesti kulttuuriperinnön tutkimuksen oppiaineen tutkimuksellisten painopistealueiden pirtaan. Oppiaine olikin konferenssissa hyvin edustettuna, sillä työryhmissä kuultiin kulttuuriperinnön 
tutkimuksen jatko-opiskelijoiden puheenvuoroja monipuolisista aiheista.

Konferenssi alkoi keskiviikkoiltana Porin kaupungintalolla järjestetyllä vastaanotolla, jossa Tarton yliopiston kulttuurintutkimuksen professori Kristin Kuutma lausui Heritage and Individuals -työryhmän puolesta kulttuuriperintöä luotaavat avaussanat. Toden teolla keskusteluihin päästiin käsiksi torstaina kulttuuriperinnön professori Outi Tuomi-Nikulan (kulttuurituotannon ja maisemantutkimuksen koulutusohjelma, Turun yliopisto), Ethnos ry:stä ja Tulevaisuuden tutkimuskeskusta edustaneen dosentti Katriina Siivosen (Ethnos ry., Tulevaisuuden tutkimuskeskus, Turun yliopisto) ja Suomen Kansantietouden Tutkijain Seuran esimiehen, dosentti Tuulikki Kurjen avaussanojen siivittäminä. Torstaina Satakunnan Museolla vietetty iltajuhla tarjosi kulttuuriperintöä muun muassa kansanmusiikin muodossa. Vielä lauantaina konferenssiosallistujilla oli mahdollisuus tutustua opastetusti maailmanperintökohde Vanhaan Raumaan.

\section{KENEN KULTTUUURIPERINTÖ? MIKÄ KULTTUURIPERINTÖ?}

Konferenssin ensimmäisenä keynote-puhujana toimi apulaisprofessori Lucky P.C. Belder (Centre for Intellectual Property Law, Utrechtin yliopisto, Alankomaat). Hän käsitteli lainsäädännöllisestä näkökulmasta lakien ja kansainvälisten sopimusten kautta yksilön oikeutta osallistua kulttuuriseen elämään ja siten myös kulttuuriperintöön. Belderin puheenvuoro oli oiva johdatus yhteen konferenssin kantaviin teemoihin - kuka omistaa kulttuuriperinnön, kenellä on oikeus kulttuuriperintöön. Kulttuuriperinnön omistamiskysymys tuli ajankohtaiseksi erityisesti toisen maailmansodan jälkeisessä tilanteessa. Tuolloin syntyneet säädökset ja sopimukset määrittelivät nimenomaan säilyttämis- ja omistamiskysymyksiä. Sittemmin sopimuksissa on syvennytty myös yksilönoikeuksien määrittelyyn.

Kiinnostavana esimerkkinä Lucky P.C. Belder käsitteli kansanperinteen ja yleensä aineettoman kulttuuriperinnön suojelua. Alkuvaiheen askeleena kohti aineettoman kulttuuriperinnön suojelua voidaan pitää vuotta 1963, jolloin Tukholmassa tehtiin tekijänoikeuksia määrittelevään Bernin sopimukseen lisäys: "Sellaisten julkaisemattomien teosten osalta, joiden tekijän henkilöllisyyttä ei tiedetä, mutta jonka kuitenkin on perusteltua aihetta olettaa olevan liittomaan kansalainen, tuolla maalla on oikeus lainsäädännössään määrätä toimivaltainen viranomainen edustamaan tekijää sekä pitämään huolta hänen oikeuksistaan ja toteuttamaan niitä liittomaissa." Vuonna 1982 UNESCO/ WIPO (The World Intellectual Property Organization) tarttui erityisellä ohjelmalla musiikillisen, kirjallisen tai muun taiteellisen tuotannon, joka on sukupolvesta toiseen kulkenut suullisesti muuttumattomana sukupolvelta toiselle, suojelu- ja omistuskysymyksiin. Vuosituhannen vaihteeseen tultaessa sopimukset laajenivat

1 Asetus Pariisissa vuonna 1971 tarkistetun kirjallisten ja taiteellisten teosten suojaamista koskevan Bernin yleissopimuksen voimaansaattamisesta ja sen eräiden märäysten hyväksymisestä annetun lain voimaantulosta, 15.4. http:/ / www.finlex. fi/fi/sopimukset/sopsteksti/1986/19860079 
(esimerkiksi UNESCOn Convention on the Safequarding of Intangible Heritage, Wipo draft sui generis instrument). Kansanperinteen suojelemisen keskusteluissa on vuosien mittaan kuljettu yksilöiden suullisten ilmausten suojelemisesta kulttuuriperinnön aineettomiin ilmenemismuotoihin.

Belder puhui myös kulttuuristen oikeuksien suojelusta. Ihmisoikeuksien yleismaailmallinen julistus määrittelee oikeuden osallistua yhteisön kulttuurielämään. Julistuksen 27. artiklan mukaan "1. Jokaisella on oikeus vapaasti osallistua yhteiskunnan sivistyselämään, nauttia taiteista sekä päästä osalliseksi tieteen edistyksen mukanaan tuomista eduista. 2. Jokaisella on oikeus niiden henkisten ja aineellisten etujen suojaamiseen, jotka johtuvat hänen luomastaan tieteellisestä, kirjallisesta tai taiteellisesta tuotannosta.” ${ }^{2}$ YK:n alkuperäiskansojen oikeuksien julistus puolestaan määrittelee artiklassa 11 alkuperäiskansojen oikeutta harjoittaa ja elvyttää kulttuuriperintöään ja artiklan 31 paragrafissa 1 alkuperäiskansojen oikeudesta kulttuuriperintönsä, perinnetiedon ja perinteisten kulttuurin ilmenemismuotojen ylläpitämiseen, kontrollointiin suojelemiseen ja kehittämiseen. Vuonna 2010 First comment UN Expert on the Rights to Cultural Heritage määritteli kulttuuriin saavutettavuutta, oikeutta oikeutta vapaaseen ilmaisuun ja kulttuuri-identiteetin kehittämiseen, sekä näihin liittyviä suojatoimenpiteitä.

Kulttuuriperinnön semantiikasta, kulttuuriperinnön luonteesta, sen läsnäolosta ja valikoitumisesta, puhui perjantaina professori Ingo Schneider (Institute für Geschichtswissenshaften und Europäische Ethnologie, Innsbruckin yliopisto, Itävalta). Hänen puheenvuoronsa teemoina olivat kulttuuriperinnön läsnäolo kaikkialla, "perinnön keksiminen", perintö selektiivisenä ja eksklusiivisena traditiona sekä maailman perinnössä eläminen tai aineettoman kulttuuriperinnön kanssa eläminen.

Kulttuuriperintökeskustelu lähti liikkeelle toisen maailmansodan jälkeisessä tilanteessa, jolloin myös UNESCOn rooli kulttuuriperinnön määrittelyissä voimistui. Kuitenkin vasta vuonna 1989 UNESCOn yleiskokous teki suosituksen perinnekulttuurin ja kansanperinteen suojelemisesta. Ingo Schneiderin mukaan kulttuuriperintö ei ole ainoastaan (meta)kulttuurista, vaan kyse on aina myös poliittisista intresseistä, vaikutuksista ja vallasta. Kulttuuriperinnön tekemiseen osallistuminen tai osallistumattomuus lähtee erilaisista yksilö- ja yhteisötasojen päämääristä.

\section{KULTTUURIPERINNÖN POLKUJA}

Kansanmusiikin professori Hannu Saha (Kansanmusiikin osasto, Sibelius-Akatemia) puhui torstain toisena keynote-puhujana Kaustisista perinteisen kansanmusiikin ja nykykansanmusiikin keskuksena Suomessa. Hän käsitteli musiikkia ja kansanmusiikkia kulttuuriperintönä, kansanperinteen elpymistä esimerkkinään kansanmusiikin elpyminen, Suomea ja Kaustista, Konsta Jylhää idolina ja symbolina sekä jatkuvaa kehitystä esimerkiksi kansanmusiikin koulutuksen kautta. Sahan käsittelemä Kaustinen

2 http://www.ohchr.org/EN/UDHR/Pages/Language.aspx?LangID=fin, 15.10.2011. 
oli tunnettu musiikistaan jo 1800-luvulla. Toden teolla kaustislainen kansanmusiikki nousi uudelleen voimiinsa vuonna 1969, kun ensimmäinen Kaustisen kansanmusiikkifestivaali järjestettiin. Kaustisen herääminen oli osa 1960-luvun kansanmusiikin elpymistä, mikä ilmeni myös sen läpilyömisenä radiossa, televisiossa sekä tansseissa. Vuosien saatossa Kaustisen kansanmusiikkifestivaali kasvoi ja kasvoi. Kaustinen sai Pelimannitalon, Kansantaiteenkeskuksen, Kansanmusiikki-instituutin ja ammatillisen kansanmusiikkiyhtye Tallarin, Suomen kansansoitinmuseon ja niin edelleen.

Yhtenä osana puheenvuoroaan Hannu Saha käsitteli Konsta Jylhää ja tämän yhtyettä, Kaustisen purpuripelimanneja. Vuonna 1952 perustetun yhtyeen menestyksestä kertoo muun muassa yhtyeen vuonna 1972 saama kultalevy. Saha kuvasi Konsta Jylhää perinteen elvyttäjänä ja innovaattorina. Jylhää voidaan pitää esimerkkinä siitä, miten suuri merkitys yhdellä henkilöllä voi olla yhdelle tapahtumalle.

Tämän aineettoman kulttuuriperinnön, kansanmusiikin, tie on vienyt menneestä uudelleen voimistumisen kautta kohti uutta kehitystä ja muotoutumista muun muassa kansanmusiikin koulutuksen muodossa. Hannu Saha totesi, että musiikillinen traditio ei ole koskaan pysynyt paikallaan, vaan se on ollut aina kehityksessä ja jatkuvassa muutoksessa. Sahan esiin nostamassa koulutuksen filosofiassa, pedagogiikassa ja metodologiassa painottuivat paitsi perinteinen suullisen tiedon kautta oppiminen, myös uuden luominen perinteitä tutkimalla ja arkistoaineistoja hyödyntämällä.

Seminaarin viimeisenä keynote-puhujana oli Kalevalan käännösten kulttuurihistoriaan liittyvässä teoshankkeessa työskentelevä folkloristi, toimittaja Petja Aarnipuu. Hän puhui Kalevalasta, sen levittäytymisestä käännösten kautta halki maailman. Jo pian Elias Lönnrotin julkaistua Kalevalan vuonna 1835 teos käännettiin ranskaksi ja venäjäksi. Uuden Kalevalan (1849) julkaisemisen jälkeen käännöksiä on ilmestynyt tasaisesti. Vuoteen 2011 mennessä Kalevala on käännetty jo 64 kielelle ja eri versioita on yli 200. Monet kääntäjistä ovat olleet ulkomailla asuvia suomalaisia tai heillä on ollut jonkinlainen side Suomeen. Kääntäjillä on ollut monenlaisia motivaatioita käännöstyöhön, Aarnipuu mainitsi esimerkiksi runoudesta lumoutumisen, poliittiset tarkoitusperät ja kulttuurin lähettiläänä toimimisen.

\section{ERILAISIA KULTTUUURIPERINTÖJÄ}

Työryhmien teemoina olivat perintö, viestintä ja yksilöt, perintö ja identiteettipolitiikat, perintöön ja yksilöihin liittyvät kysymykset, perinnön suojeleminen, käsityö ja design, kehittyvä aineellinen kulttuuriperintö sekä perintö taloudellisena välineenä. Puheenvuoroissa esimerkiksi erilaiset kulttuuriperinnön muodot ja tasot nousivat esiin.

Oma työryhmäpuheenvuoroni kulttuuriperinnöstä inkerinsuomalaisten paluumuuttokerronnassa oli perintöä ja identiteettipolitiikkaa käsitelleessä työryhmässä. Samassa työryhmässä professori Swietlana Czerwonnaja (Nicolaus Copernicus University, Department of Ethnology And Cultural Anthropology UNC in Torun, Poland), joka toimi myös työryhmän puheenjohtajana, käsitteli suomalaisugrilaisen taiteen kautta kulttuuriperinnön ilmenemismuotoja. Peter F.N. Hoertz (Georg-August-University, Department for Cultural Anthropology / European Ethnology Germany, Göttingen) 
käsitteli toiseutta resurssina identiteetin rakentamisessa erilaisten juutalaisen kulttuuriperinnön hyödyntämisten kautta. Historian tutkija Mika Suonpää puolestaan käsitteli brittiläisessä parlamentissa käytyjä kulttuuriperintökeskusteluja.

Heritage and Individuals -konferenssi toi yhteen kulttuuriperinnön asiantuntijoita eri puolilta maailmaa, yhteensä viidestätoista eri maasta. Keskustelujen vilkkaus, aiheiden moninaisuus ja konferenssiosallistujien innostuneisuus osoitti, että kulttuuriperinnöstä riittää varmasti keskusteltavaa myös tuleviin tapaamisiin.

Filosofian maisteri Minna-Liisa Salonsaari on kulttuuriperinnön tutkimuksen jatko-opiskelija Turun yliopiston Kulttuurituotannon ja maisemantutkimuksen koulutusohjelmassa Porissa. Vuosina 2010-2011 hän on työskennellyt tohtorikoulutettavana Suomen Akatemian rahoittamassa Vieraita idästä-hankkeessa. 